Propuesta de diseño para un enfoque interdisciplinario de la educación ambiental: Análisis teórico de una práctica innovadora

\title{
Design proposal towards an interdisciplinary approach to environmental education: Theoretical analysis of an innovative practice
}

\author{
José Gómez Galán. \\ Universidad de Extremadura. \\ \& Universidad Ana G. Méndez. \\ jogomez@uagm.edu
}

Olga Figueroa Miranda.

Arecibo Observatory-YEI, Puerto Rico. olga.figueroa@yangenterprises.com

Cristina Lázaro Pérez.

Universidad de Murcia.

cristina.lazaro2@um.es

José Ángel Martínez-López.

Universidad de Murcia.

jaml@um.es

\section{RESUMEN.}

La protección del medio ambiente se ha convertido, sobre todo en los últimos decenios, en un relevante tema que preocupa a las personas y que está muy presente en los programas políticos europeos e internacionales. Uno de los medios más útiles para potenciar la concienciación sobre el cuidado del medio ambiente y la lucha contra el cambio climático es la educación ambiental. Sin embargo, se trata de una especialidad aún no especialmente definida, que en los ámbitos educativos se ofrece de diferentes maneras (como una asignatura independiente, de modo tangencial respecto a otras, dentro de la educación para las ciencias, etc.). Este trabajo defiende la necesidad de una educación ambiental interdisciplinaria que pueda desarrollarse en cualquier asignatura. Presenta, a través de una metodología cualitativa y descriptiva, el análisis teórico de una práctica formativa innovadora en el contexto de la educación secundaria y desde la perspectiva de varias especialidades, centrada en la descripción del pasaje en la Europa de la Edad Media. El resultado ofrecido es un modelo de programación de aula, articulado a través de una monografía didáctica como base de la práctica, que es presentado como ejemplo para la implementación de nuevas propuestas de diseño instructivo de la educación ambiental desde un enfoque interdisciplinario. La presencia de los problemas ambientales en cualquier asignatura y temática ofrece el mejor marco para los procesos de sensibilización tan necesarios hoy en día.

PALABRAS CLAVE.

Educación Ambiental, Teoría de la Educación, Paisaje, Historia, Formación del Profesorado.

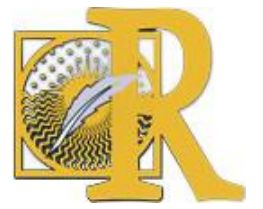




\section{ABSTRACT.}

Environmental protection has become, especially in recent decades, a relevant issue that concerns people and that is very present in the European and international political agendas. One of the most useful means of raising awareness of the environment and the fight against climate change is environmental education. However, this is a specialty not yet specially defined, which in the educational fields is offered in different ways (as an independent subject, tangential to others, within science education, etc.). This work aims to defend the need for an interdisciplinary environmental education that can be presented in any subject. It presents, through a qualitative and descriptive methodology, the theoretical analysis of innovative educational practice in the context of secondary education and from the perspective of several specialties, focused on the description of the passage in the Europe of the Middle Ages. The result offered is a model of classroom programming, articulated through a didactic monograph that is the basis of the practice, which is offered as an example for implementing new proposals for instructional design of environmental education from an interdisciplinary approach. The presence of environmental problems in any subject and theme offers the best framework for the awareness processes so necessary today.

KEY WORDS. Environmental Education, Educational Theory, Landscape, History, Teacher Training.

\section{Introduction.}

As advocated by Frantz and Mayer (2014) "environmental education imparts knowledge and creates an experience to change beliefs, attitudes, and most importantly, behavior". Over time, environmental education is becoming significantly more important. Society is increasingly sensitized to one of the biggest problems facing humanity and, logically, the educational context may offer an answer to it. The question, of course, is how to develop adequate programs of environmental education that is not only integrated with regards to the curriculum but offer significant results. Essentially, we take into account that the greater diversification of training designs in environmental education will mean an increase concerning the experiences in this complex field, in such a way that we can determine programs adapted to the diverse educational levels, and the characteristics of the students, as we have done on various occasions for different objects of study (Gómez Galán and Mateos, 2003; Gómez Galán, 2010, 2015a and 2015b).

Also, needless to say, it should consider the geographical space in which they are applied, although we could start from a series of general considerations (as they have already been developed in the different international seminars on environmental education, to which we will refer later) that would be applied according to the educational framework in the following levels of curricular concretion. Starting from this point of view we defend the need to offer innovative designs of environmental education (which must be evaluated from a formative rather than summative perspective) in the different areas of the primary and secondary education curriculum, supported above all in interdisciplinarity and/or transversality (with the preference of the former). Every educational process must be endowed, and environmental education would be a paradigmatic case, from a holistic perspective derived from the fact that all the

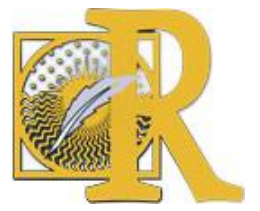


problems we face have interconnections and common characteristics, and also in that they start from the same roots that we consider unquestionable in the ethical and moral domains (Gómez Galán, 2010, 2016a and 2017).

Of course, this proposal involves different pedagogical advantages, such as establishing a direct relationship between the curricular contents in such a way that allows the development of a better understanding of the problems surrounding the environment, and that starting from the knowledge already acquired by the students, from a constructivist dimension, we can achieve in a more effective way the objectives pursued. It is also possible to achieve a more solid integration, avoiding the fragility that transversality often offers, which not only depends on educational programs but also personal training and interest.

The necessary interdisciplinarity should not be reduced to transversality. It can be achieved, for example, by integrating it into the main curricular areas, as we propose. In this sense, the main objective of this article is to present a classroom programming model, articulated through a didactic monograph applicable to the first cycle of secondary education, which can serve as an example of this approach that we consider so necessary today in environmental education. The methodology used was of a qualitative type, to organize the theoretical framework and the description of the practical dimension. It is situated within a much broader basic and descriptive research, aiming with this contribution to present one of the most innovative resulting elements.

All experience in the field of environmental education can be positive due to its importance in current educational processes (Wals, Brody, Dillon and Stevenson, 2014; Gómez Galán, 2009 and 2014; Kopnina, 2015; Van Poeck and Lysgaard, 2016; Granit-Dgani, Kaplan and Flum, 2017; Henderson and Zarger, 2017; Herman, Sadler, Zeidler and Newton, 2018; AarnioLinnanvuori, 2019; Ilesanmi, 2019: Jorgenson, Stephens and White, 2019). And their development practical is key (Chen and Martin, 2015; Nakagawa, Verlie and Kim, 2020). We must achieve greater efficiency, both from a qualitative point of view (continuous improvement of the designs), and quantitative (a greater application: educational levels and geographical space) since without the change of attitudes, and awareness increasingly decisive concerning the recognition of the environment (with all that implies, that is, in line with an ethical and moral development), it will be impossible to move forward. The basis is not only supranational, governmental, or powerful business decisions. The basis of the change process is, undoubtedly, education.

\section{Foundations of an innovative educational design in environmental education.}

The overall objective of environmental education is seen as the development of the pupils' action competence (Breiting \& Mogensen, 1999). Nevertheless, as we have pointed out, environmental education, more than a set of transversal contents that in many occasions are addressed with little significance in educational centers, should also be integrated in the formative sense that is included in the educational laws, and by the transcendence that today it undoubtedly has, within the main curricular areas. This is a problem that was faced at once when it was decided to integrate environmental education into educational processes, as underline by a classical study of Pérez Torras (1992). However, the current situation is not much better, and therefore its insertion is proposed, at least in its main objectives, in other

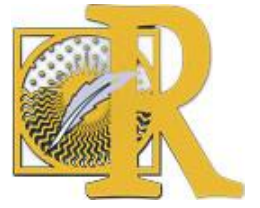


curricular areas. For example, it would be ideal in all those areas related to knowledge of the natural, social and cultural environment, natural sciences, social sciences, geography, biology, geology, earth and environmental sciences, human and economic geography, etc., depending on the educational level.

Needless to say, it could also be present in an indirect way in many other areas or curricular subjects, in direct relation with their characteristic contents (for example, in history, or history of art, and we might think of those that, a priori, would give the impression that there is no room for environmental education). It would then be possible and appropriate to study, for example, the landscape throughout history, which would help the student to understand how the human being influences the same and is precisely something that we will focus on in the proposal offered). As we have intended, interdisciplinarity is maintained. The variety of contents offered in the areas indicated is very vast (environmental sciences, geography, history, sociology, etc.) to allow an understanding of the construct on the student's part, and comprehend that current problems are not isolated in compartments. They are indeed tight, but take into account the causes and consequences present in the historical, social, technological, cultural, and political developments that characterize human activity.

For this proposal, which could be specified in certain teaching units or a didactic monograph, it would be necessary to establish general objectives that would be the basis of any interdisciplinary educational design of environmental education (Gómez Galán, 2018a). In that sense, we can say that there is a certain consensus at the international level. At the Tbilisi Conference on Environmental Education, organized by UNESCO and UNEP (United Nations Program for the Environment), it was established that environmental education is "the process through which the concepts about the processes that occur in the framework of nature, facilitates the understanding and assessment of the impact of relationships between man, his culture and natural processes, and above all encourages a change of values, attitudes, and habits that allow the development of a code of conduct for issues related to the environment" (UNESCO, 1980). As we can see, its relationships with human beings, culture, and natural processes are underlined, which consequently implies an interdisciplinary study (Gómez Galán, 2015c and 2019; Wals, Weakland, \& Corcoran, 2017; Dale, Powell, Stern and Garst, 2020). Therefore, in this conference, which includes a large part of the guidelines already collected in the International Seminar on Environmental Education in Belgrade in 1975, it was proposed that three basic objectives were necessary to design environmental education programs: (a) Know conceptually the functioning of natural systems; (b) Evaluate the human impact as a consequence of the alteration of said natural systems, and (c) Promote an attitudinal change of people concerning the environment.

Already at that time, and although this perspective was lost later, an interdisciplinary approach to environmental education was advocated. At the beginning of the 1980s, the 1st Conference on Environmental Education (Nieda, 1983) established the following methodological guidelines for their development:

- $\quad$ An interdisciplinary treatment will be carried out.

- $\quad$ An active methodology will be used, which favors reflection, reasoning, and critical thinking.

Cooperation and discovery will be stimulated.

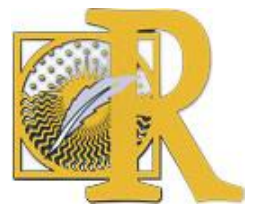

Fecha de recepción: 13-11-2020 Fecha de aceptación: 15-11-2020

Gómez-Galán, J., Figueroa-Miranda, O., Lázaro-Pérez, C., \& Martínez-López, J. A. (2021). Propuesta de diseño para un enfoque interdisciplinario de la educación ambiental: Análisis teórico de una práctica innovadora International Journal of Educational Research and Innovation (IJERI), 16, 142-161 ISSN: 2386-4303 DOI https://doi.org/10.46661/ijeri.5424 
The medium will be taken as a starting point for the study, subsequently addressing other means and making comparisons.

- $\quad$ The intellectual possibilities of the students will be taken into account as a reference.

- $\quad$ Well organized and structured activities will be proposed.

- $\quad$ A team effort will be made to review, analyze, and solve the problems that arise.

- $\quad$ Be evaluated, in addition to knowledge, habits, and attitudes.

In the 1990s, as international knowledge of the consequences of human activity on the environment, from the destruction of the ozone layer to climate change, grew, the importance of environmental education was emphasized, as well as the need for an interdisciplinary approach. The Treaty of the Global Forum of Civil Society held in Rio de Janeiro, Brazil, stated that "Environmental education must be based on critical and innovative thinking, at any time and place, in its formal, non-formal and informal expressions, promoting the transformation and construction of society "(MOPTMA, 1994).

As we can see, this important forum refers to the interdisciplinary characteristics of environmental education, as presented herein. The objectives, therefore, are obvious. It is about changing the nefarious actions of the population against the environment, as a measure to stop the continuous deterioration of the biosphere and to be aware of the seriousness of the problem we are facing, in which the future of the environment is at stake: Life on Earth, which naturally includes the human being himself. It is an objective that can be pursued from any curricular area.

\section{Returning to the interdisciplinary nature of environmental education}

However, already in the mid-1990s and during the first two decades of the 21st century, until today, there is a trend in which environmental education is losing this initial globality to be placed in specific areas, especially within the didactics of science (Author). Why did this phenomenon occur? There would be different explanations for this. Sauvé (1999) already reflected the main ones in those initial moments: (a) on the one hand, that Environmental Education is not well seen today when it is associated with elements of social and educational criticism, which puts into question common practices or ideas, with which it tends to be offered within a very specific framework, losing its authentic interdisciplinary nature and focusing on merely ecological aspects; and (b) on the other hand, that different proposals of integral education were appearing that contemplate all the essential aspects of human development, in which environmental education only occupies a plot of land, incurring in a marked reductionism. Among these proposals is the Education for Sustainable Development, the Education for Sustainable Future, the Sustainable Education or the Education for Sustainability, etc.

In practice, this approach has not been sufficiently effective from a methodological or training point of view. Proof of this is the diversity of ways of presenting environmental education according to countries and/or educational levels (Authors; Ardoin, Bowers and Gaillard, 2020). Therefore, it would be convenient, and we insist on it, that it resumes its initial interdisciplinary nature, and is contemplated in the most diverse subjects. This would allow, for example, subjects such as geography and history to contribute to raising awareness of environmental problems and thus participate in the foundations of environmental education.

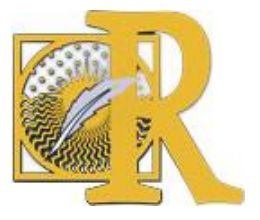

Fecha de recepción: 13-11-2020 Fecha de aceptación: 15-11-2020

Gómez-Galán, J., Figueroa-Miranda, O., Lázaro-Pérez, C., \& Martínez-López, J. A. (2021). Propuesta de diseño para un enfoque interdisciplinario de la educación ambiental: Análisis teórico de una práctica innovadora International Journal of Educational Research and Innovation (IJERI), 16, 142-161 ISSN: 2386-4303 DOI https://doi.org/10.46661/ijeri.5424 
Moreover, it is necessary to bear in mind that many other elements are present in the teachinglearning process and that should also be analyzed in the process. In addition to the epistemological dimension, the psycho-pedagogical and curricular aspects, school life and the specific initiatives of the environmental education must be taken into account (activities or experiences such as nature classrooms, itineraries, etc.). As can be seen in figure 1, adapted from the one proposed by Busto, García, Fernández, and Vázquez (1982), they would all be interrelated and dependent elements, which should be considered together as a whole in all training design in this field:

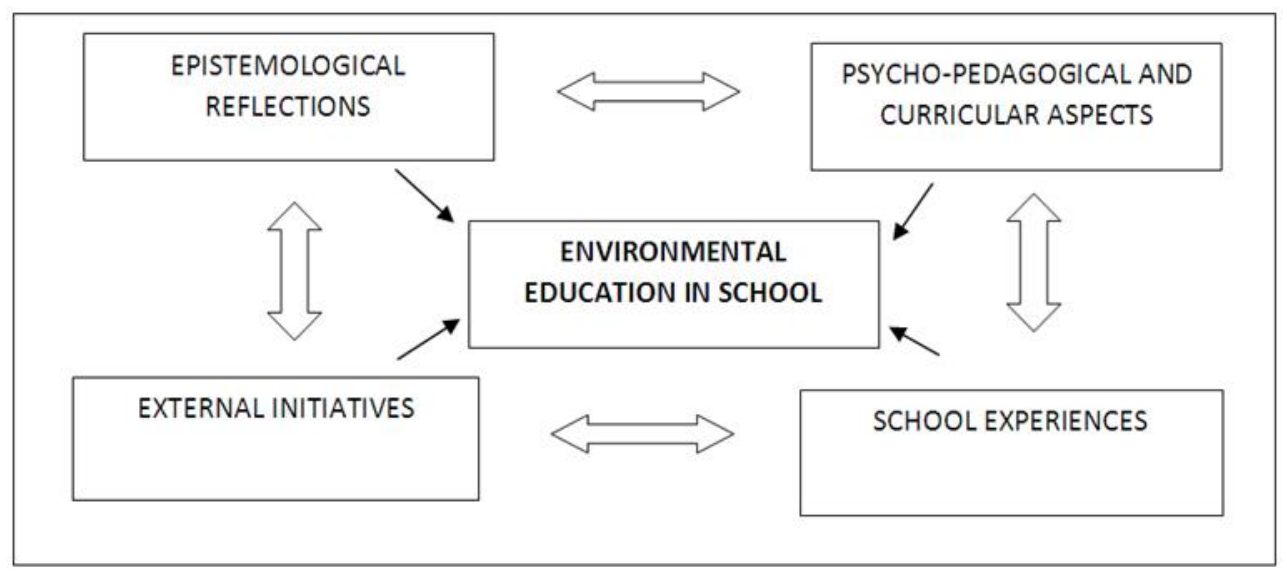

Figure 1. Environmental education in the school: Confluent aspects of the analysis. Source: Busto, García, Fernández, and Vázquez (1982)

Of course these elements, that must be present in any environmental education program, should be added in all matters related to society, and this demand is operative at any given time (and today we can talk about serious environmental problems), as well as the interests and conceptions of the learner. In the direct relationship with the content that each academic discipline offers, school knowledge will be built around the conception of the whole being (figure 2). It is about the authentic knowledge that is offered as training aimed at the needs of any future citizen. In this sense, each problem would enter into a curricular hypothesis where the research process would lead to the knowledge acquired by the students. As pointed out by Porlan and Rivero (1994): "it is, therefore, [...] to establish tentative hypotheses of school knowledge [...] that describe, at the same time, different evolutionary formulations of a certain what (the problems and the meanings that try to explain it), and the facilitator elements of the construction process (the difficulties and obstacles, as well as the conceptual, attitudinal and procedural keys that can facilitate the overcoming of them) ".

In the context of school knowledge, environmental education must occupy a priority dimension. Precisely because of their characteristics, many authors defend the relevance of their interdisciplinary integration in the academic curriculum, regardless of the way it is carried out or the educational level at which it is done (Palmer, 2002; Öhman, 2016; Castillo, 2017; Jickling \& Sterling, 2017; Tillmanns, 2020). The important thing, in all cases, would be an authentic integration that would guarantee knowledge in this field.

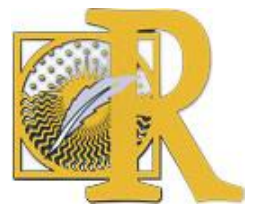




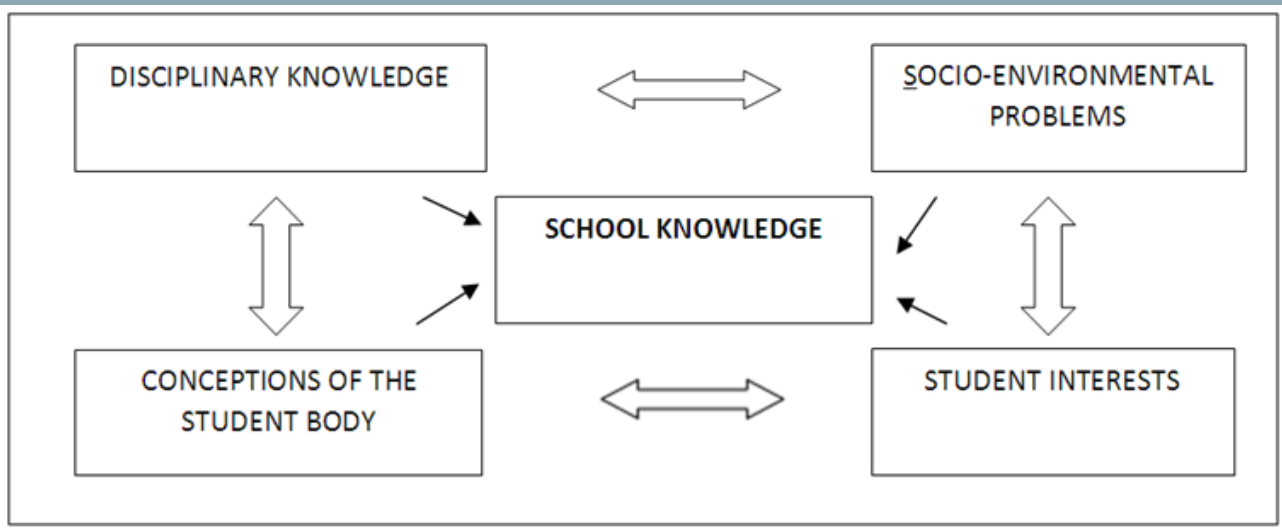

Figure 2. School knowledge: Constituent parts. Source: Elaborated by the authors

Therefore, we would place ourselves in a research context, in which interdisciplinarity becomes obligatory if we wish to advance and deepen our object of study. In the case of Environmental Education, the student must be able to analyze from a critical perspective all the information that comes to him or her from different media; we must offer the student the possibility of delving into the concepts already acquired and check if they are true, that one knows seriously and rigorously the problem, and be aware of it at the same time so that we are able through a process of motivation to awaken their interest and concern, the very bases of awareness and sensibility (Gómez Galán, 2010). And all this is possible from a specific academic discipline, as we are defending, that allows you to establish direct relationships for a better understanding of the problems of our world. All this is, in short, a research process that must start in the teacher, for example from methodological and scientific models such as action research (Elliot, 1990; Glanz, 2014; Mertler, 2016) that can lead to innovative experiences, and of the students themselves in the process of discovery explorations, naturally within a constructivist dimension of learning.

In a general way, as indicated by Porlan and Rivero (1994), "these curricular hypotheses are [...] authentic scopes for school research that allow prescribing relatively and rigorously the collective processes of meaning construction, but that admits, also, given precisely its hypothetical condition, differentiated developments, adapted to each specific school context". And this is precisely the context in which the bases can be established to face the problem from the interdisciplinary perspective. We believe that there are topics appropriate for this purpose, the paradigmatic case would be the landscape, studied for instance in the field of geography and history (Casas and Erneta, 2015; Garcia de la Vega, 2014; Madeluero, 2005; Martínez \& Arrebola, 2016). From the same context, the students could acquire knowledge on different historical epochs that allow them to know better the elements related to the culture, the economy, the society, etc. of each separate yet related discipline, that would allow one to be able to understand how the human being interacts with the environment, in such a way that inappropriate use of it is harmful both to the environment and to the individual.

This concrete objective, therefore, would be common both for the area of social sciences and humanities (specifical history) as of the natural sciences (in the main framework of environmental education). The transversality becomes inter-disciplinarity, which

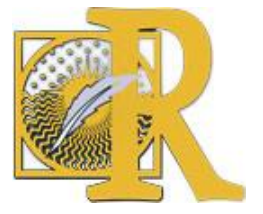

Fecha de recepción: 13-11-2020 Fecha de aceptación: 15-11-2020 
simultaneously establishes a direct relationship, the same objective, to and for two areas theoretically different, but closely interrelated. It would be, in short, authentic curricular transversality, that in no way supplies different contents in so many cases decontextualized without any reason for it. Therefore, didactic units could be designed that start from this educational philosophy for its integration into an innovative and interdisciplinary overall programming. For example, one that would focus on the relationship between landscape and history. The educational environment might concretely address itself to the following subject: The Landscape in the Europe of the Middle Ages, as we have described (Gómez Galán, 2004 and 2018b).

The main objective would be that the students can understand how the human being, in its interaction with the environment, modifies and transforms it, and the landscape that he or she observes in their locality or region can be very different from the one that other people in the past knew. This is intended to warn us about the power we have today against nature and the biosphere, and the importance of respect and conservation of it, considering how the current serious situation in which our planet finds itself due to the direct action of the human being, within a complex historical process. Also, this perspective would connect fully with the current concepts of holistic education (Gómez Galán, 2017).

\section{Didactic monograph model for the interdisciplinary integration of environmental education}

Of course, all educational processes, from the technological perspective of education (educational technology) that characterizes current programs, part of some objectives (what is intended to be achieved) that are obtained by offering content (what is taught and learned) through a methodology (how the subject is taught and learned). All this is checked (evaluation) both to determine to what extent these objectives have been achieved (the summative function of the evaluation) and to determine how we can continuously improve this process (training function of preparation). In the case of Environmental Education, practically all the elements of classroom programming (which naturally consist of a set of teaching units) are similar to those present in any other educational setting. However, the activities present in the methodological phase tend to be very different since they imply a direct contact between the learner and the environment, and this can only be achieved by breaking the spatial structure in which the training is traditionally carried out in a face-to-face context: the educational center (Gómez Galán, 1998). That is, to achieve the basic objectives of Environmental Education it is necessary to be in contact with nature, and this is accomplished through methodologies based on experiences and activities, such as itineraries and pedagogical routes, exploratory trails, nature classrooms, etc. (Gómez Galán, 2004, 2008 and 2018b; Chawla, 2015; Frantz \& Mayer, 2014; Otto and Pensini, 2017).

For example, some authors such as Elvira and Martí (1995) specify some of the recommended activities for Environmental Education (itinerary, ecology game, role-playing, etc.) that would involve different methodological procedures (analysis, simulation, decision making, etc.), and consequently, the use of various materials, such as transparencies, workbooks, computer products, etc. A comparative table of the recommended resources and activities can be seen in table 1.

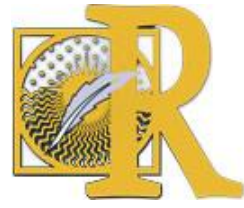

Fecha de recepción: 13-11-2020 Fecha de aceptación: 15-11-2020

Gómez-Galán, J., Figueroa-Miranda, O., Lázaro-Pérez, C., \& Martínez-López, J. A. (2021). Propuesta de diseño para un enfoque interdisciplinario de la educación ambiental: Análisis teórico de una práctica innovadora International Journal of Educational Research and Innovation (IJERI), 16, 142-161 ISSN: 2386-4303 DOI https://doi.org/10.46661/ijeri.5424 
Table 1. Educational resources and activities in environmental education. Source: Elvira and Martí (1995)

$\begin{array}{ccll}\begin{array}{c}\text { Action } \\ \text { Observation }\end{array} & \begin{array}{c}\text { Activity } \\ \text { Guided itinerary }\end{array} & \begin{array}{l}\text { Procedures } \\ \text { Analysis and } \\ \text { interpretation }\end{array} & \begin{array}{l}\text { Materials } \\ \text { Transparencies } \\ \text { work notebooks }\end{array} \\ \text { Intervention } & \text { Ecology game } & \begin{array}{l}\text { Simulation and } \\ \text { modeling }\end{array} & \begin{array}{l}\text { Computer demo } \\ \text { table games } \\ \text { computer simulator }\end{array} \\ & \begin{array}{c}\text { Nominal group } \\ \text { role playing }\end{array} & \begin{array}{l}\text { Decision making } \\ \text { group management }\end{array} & \begin{array}{l}\text { Flip chart, cards } \\ \text { computer simulator }\end{array}\end{array}$

Precisely about the methodology and materials is one of the innovative elements that we wish to propose in the didactic unit on landscape and history. We refer to one of the most used instruments in the field of social sciences and that we believe could be extremely useful for environmental education: the didactic monograph. Of course, the development of this part of the classroom could include the most common activities in the field of environmental education, which we have already mentioned above, such as the itineraries; However, as it is a didactic unit contemplated in a specific curricular area such as social sciences, geography, and history, the use of the same main tools, instruments, and materials is also very appropriate. Not only do we consider that it would be a very positive experience in Environmental Education, as it would mean a break with the usual methodological frameworks, but that we also believe it is essential for students to have access to global knowledge of the problem, and its relationship with the rest of academic disciplines (Gómez Galán, 2001 and 2018b).

A suitable case in point might be a didactic unit called, for example, Landscape and History: The European Landscape in the Middle Ages, intended for Secondary Education students and, specifically, in the educational stage comprised between 13-15 years of age. Of course, both the teaching of Environmental Education and the social sciences, and especially the interconnections between them, should contribute to the development of Compulsory Secondary Education students. The didactic monograph, we underline, would suppose an excellent curricular material for the attainment of the pursued objectives. On the other hand, due to the problems that currently children and adolescents have (the latter being especially under accusation in this educational stage) to interpret, understand. or analyze a text, we have considered convenient, as an innovation more with the experimental design model of Environmental Education, that the didactic unit that we propose is based on a text or monograph especially prepared by the teacher (that we will outline later, and that we have entitled in a similar way to the didactic unit, that is, Landscape and History: The European Landscape in the Middle Ages), for which a didactic language should be used, as attractive and as plastic as possible, but without losing any of the rigor and scientific basis it contains. In a particular way, we denominate this one in curricular material, as we have already indicated, didactic monograph. The work to be developed by the students, following a fundamental self-learning methodology, through the advice and guidance of the teacher, will

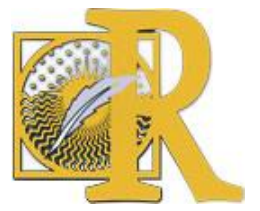

Fecha de recepción: 13-11-2020 Fecha de aceptación: 15-11-2020 
be based on the reading and analysis of the material prepared for the students, which in no way can be compared to that offered by the student's text-book, because, in addition to being adapted to the differential characteristics of the target audience, it presents the following innovative interdisciplinary elements (Gómez Galán, 2004 and 2018b):

It is a document that focuses on a thematic core from a perspective aimed at offering a joint vision of social sciences and environmental sciences. It offers, in that sense, direct relations with history, geography, earth sciences, sociology, political science, economy, etc. and the connections between the different specialties of this (for example, medieval history, human geography, demography, urban and social geography, botany and zoology, agronomy, ecology, etc.) which allows integration of knowledge and a global vision of this very broad scientific field, with its many points in common are precisely those that allow the development of knowledge, and applying this concept to the excessive specialization that sometimes occurs in this educational level and that we consider is not relevant until Baccalaureate or the university world.

The text of the monograph has been specially prepared by us, based on experience with the design and use of a multitude of curricular materials (from primary education to the university world, levels in which we have worked as a professor in different academic disciplines). It is also composed of integrated but complementary material (tables, graphs, etc.) that allows for the development of different activities. Along with this, and with the search after the fundamental objective of reading and analyzing information belonging to the Social Sciences (where it is essentially located, regardless of its projection to Environmental Education), we also intend to develop an integration between traditional media -such as written texts or printed images - and the use of new technologies, mainly the Internet and audiovisual and multimedia instruments. The use of different curricular materials to achieve the same objectives will allow the students, and consequently, the teacher, to reflect on the need for their use and not to participate in preconceived and widespread ideas; on the other hand, as we have already shown in some researches (Gómez Galán, 1999 and 2001; Gómez Galán and Mateos, 2002), here we would also wish to reflect on the superiority of some resources over others.

The framework of a didactic unit, therefore, is suitable to develop the work with curricular material, such as the didactic monograph, aimed at the learning of social and environmental sciences at the school level in a group of 3rd ESO (secondary) students of an institute of education. Besides, self-learning techniques are seen as a highly adequate methodology. The reason is that, in our case, we understand that this material, currently and always under the direction and guidance of a qualified teacher, can be a useful tool for obtaining information to enhance self-learning along didactic-methodological lines (referring too, and depending on, the educational level, a school context). Starting from these premises, we believe that in the development of this didactic unit, the use of the monograph is fundamental for the achievement of the objectives that we propose. The chosen theme, Landscape and History: The European Landscape in the Middle Ages, is of special interest since it will allow us to provide the student with a more defined view of the different elements - always dependent on each other - that have an involvement in both disciplines (society and environment), and that shape the world, the environment in which he or she lives. On the other hand, it will offer us a complete range of didactic possibilities that we collect in the set of objectives to be achieved

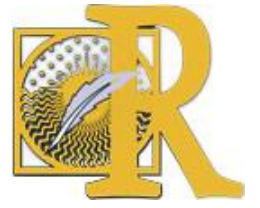


linked to the main one, which we have already explained), and that will allow their personal development and the acquisition of different capacities (Gómez Galán, 2001 and 2018b).

\section{Contents of an interdisciplinary didactic monograph focused on landscape}

The basic characteristics of the didactic monograph would be to present the contents with accessible language, but at the same time rigorous, prepared by the teacher with all the necessary documents so that the students can assimilate in the best way the proposed topic. It would be composed basically of the following sections (Gómez Galán, 2018b):

Introduction and development: the main contents are presented, consisting of a joint vision of the topic including terminology and fundamental concepts, for which we recommend the use of the textbook(s), encyclopedias, specific works, telematic sources (Internet websites, with special care, in this case, in the selection), etc. To face the aforementioned theme, that is, the landscape in the Middle Ages, it can be very useful for this first part that the teacher consults a work such as Guerreros y Campesinos [original version: Guerriers et Paysans, VIIle-XIle Siècles. Premier Essor de l'Ėconomie Européenne. Paris, Gallimard, 1973], by Georges Duby, in which the author presents the historical aspects of the Middle Ages through a synthesis of the ecological, demographic, and technological conditions, relating them to the structures of society and the characteristic factors of medieval Europe. It is, therefore, ideal to face the main objective of the didactic unit, and this will allow the teacher to pick up the main characteristics of the landscape of the Middle Ages, and the interrelations of man to the environment Nature, the clearing of ground in search of farmland, the forests in the European landscape, the fiefdom, the monasteries, and the exploitation of the land, the work tools, etc. all of these can be elements present in the didactic monograph and that Duby presents in an accessible way, allowing the teacher to offer an original and adequate material for his or her students.

- $\quad$ Selection of texts: the historical monograph will also be advisable to contain some simple texts referring to the European landscape in the Middle Ages. The sources of information may be those that we have previously enumerated, being very imprudent, as we have pointed out, in the telematics due to the poor quality present in the network, which forces the teacher to be very critical with the selected information, as we have developed profusely at another time (Gómez Galán, 2001). The students will carry out an analysis of them individually or in groups, as we will indicate later in the realization of activities, and will allow one to settle the knowledge acquired in the reading and study of the previous contents.

Graphics and images (iconic elements): both in the introduction and the development phase, it is possible to include graphics and images, which will not only illustrate and make the material more attractive, but they are also decisive, in many cases, to achieve the fundamental objectives. This is, evidently, the case of a subject such as the landscape. It is necessary to include iconic references that allow the student to reach the fundamental objectives, that is, to know the landscape in the Middle Ages. and reflect on the action during it of the society of that time. Naturally, drawings depicting the landscape at that historical moment, or current images reflecting the configuration of the medieval landscape, both urban and rural (well-preserved historic centers, towns, and villages with period architecture, forests, swamps, or similar croplands) can be used. etc.). Of course, it is also possible (and advisable)

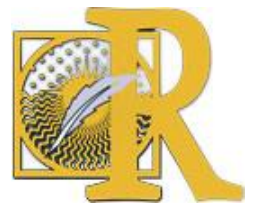


to include synoptic tables, conceptual maps, demographic and economic graphs, historical and geographical maps, tables, etc. that allow the student (and teacher) to go deeper into the questions or, in the present case, to structure the information in a more accessible way.

Given the main sections and highlights of the didactic monograph, we can show some examples of the iconic elements that we referred to earlier. For example, in the development of the contents, it would be very useful to introduce an illustrated conceptual map in which the main characteristics of a given general common age are presented, integrating with it the importance of the landscape when dealing with a rural world.

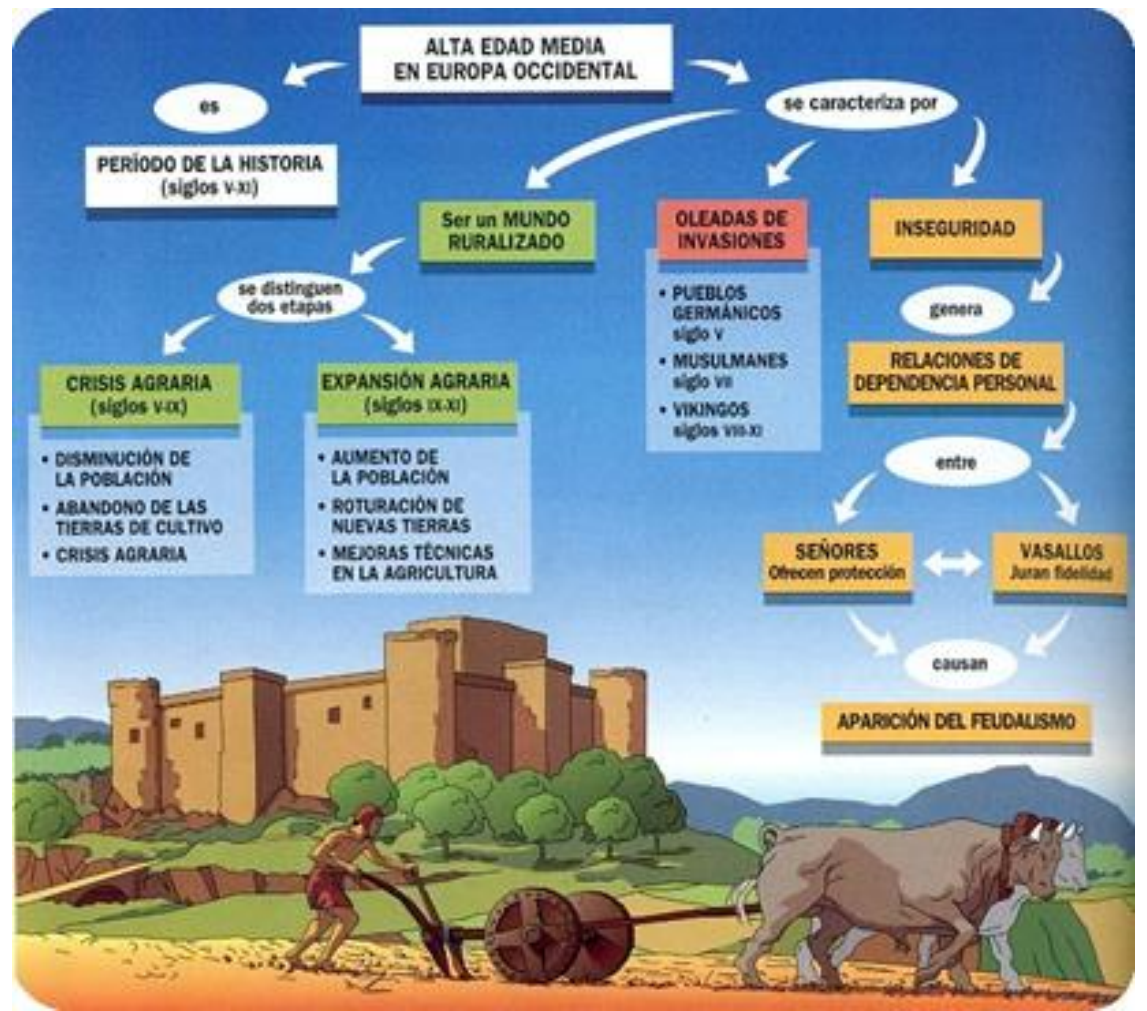

Figure 3. Illustration of a conceptual map of the importance of agriculture in the medieval landscape. Source: Educastur materials (public domain).

Of course, the fief is the essential unit of political and socio-economic structure of the Middle Ages, fundamental to understand a landscape characterized by an agricultural and livestock farm around a center of power such as the castle or the monastery. In this case, and being a structure as one says far from what the student currently knows, it might be useful to facilitate this work by introducing a schematic-iconic framework, and again in respect to the age of the students would equally be very interesting, composed of images, which would allow one to assimilate this information in a more accessible way. Of course, the teacher must explain all the elements present in it, and that characterize the medieval socio-economic structure and consequently the environment (the castle, the forest, the farmland and the fallow, the communal meadows, the village; and concepts such as tithe, income, etc.).

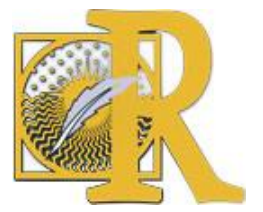




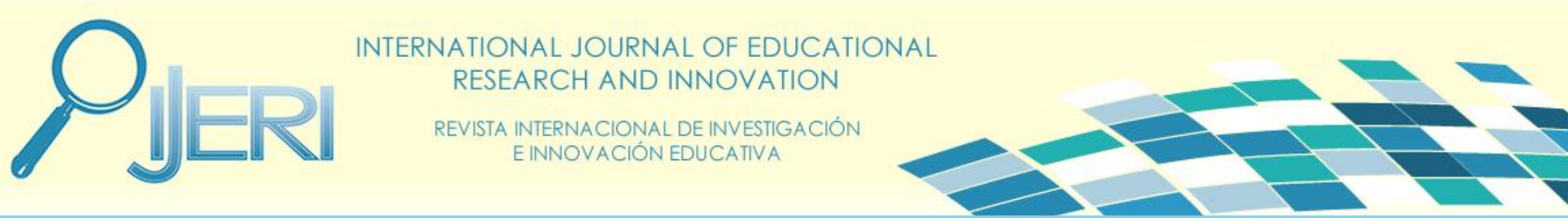

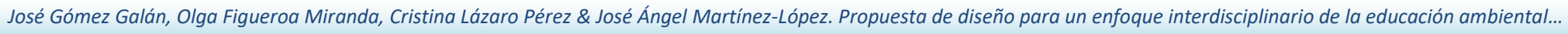

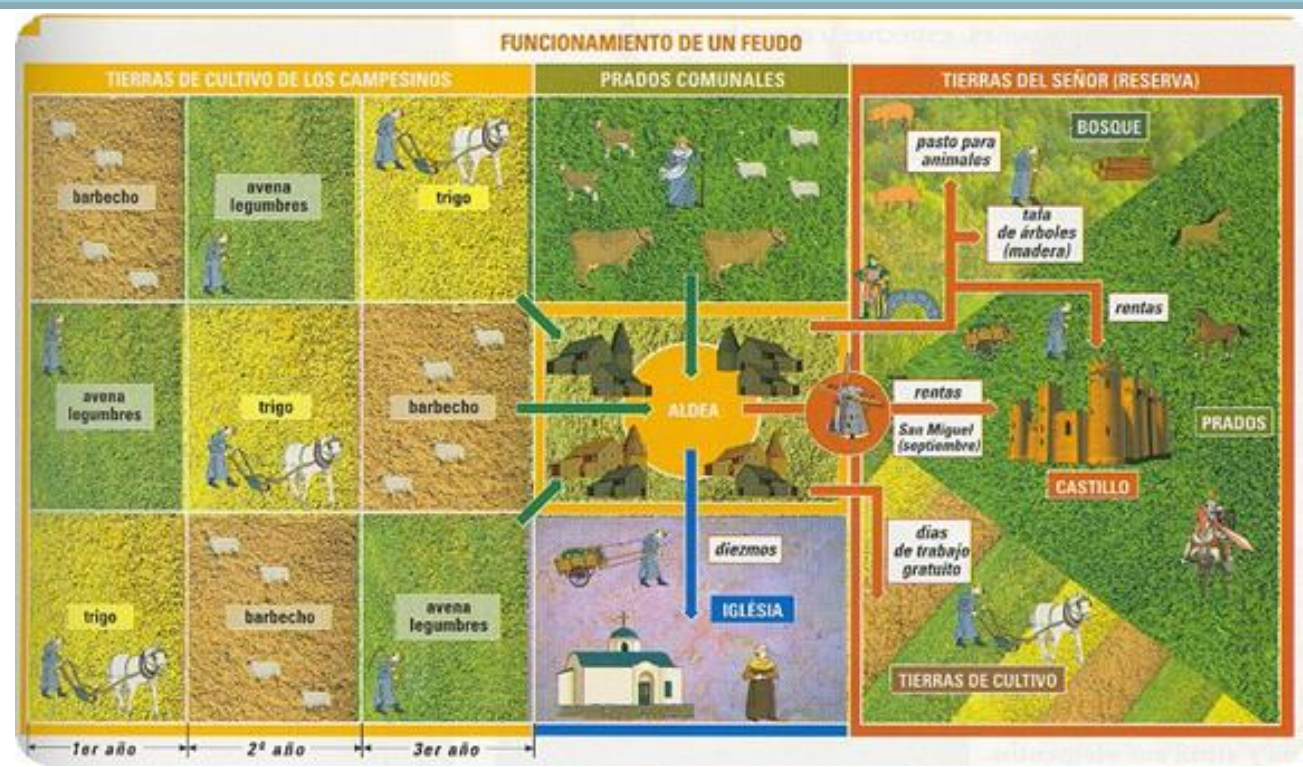

Figure 4. Schematic-iconic framework on socio-economic structure and landscape in the Middle Ages. Source: Educastur materials (public domain).

And finally, as we indicated above, one can include current images that recreate the architecture and the agricultural landscape of the time, and that we recommend merging with drawings in which it is possible to introduce interpretative elements for the student. Of course, in all cases, it is possible to develop activities related to these iconic elements. For example, in this last table, one might ask the students to determine the activity that they observe in the image on the right, and reflect on the question of whether it is constitutive only of the medieval landscape, or is also applicable to the present day (Gómez Galán, 2004, 2008, 2016b and 2018b).

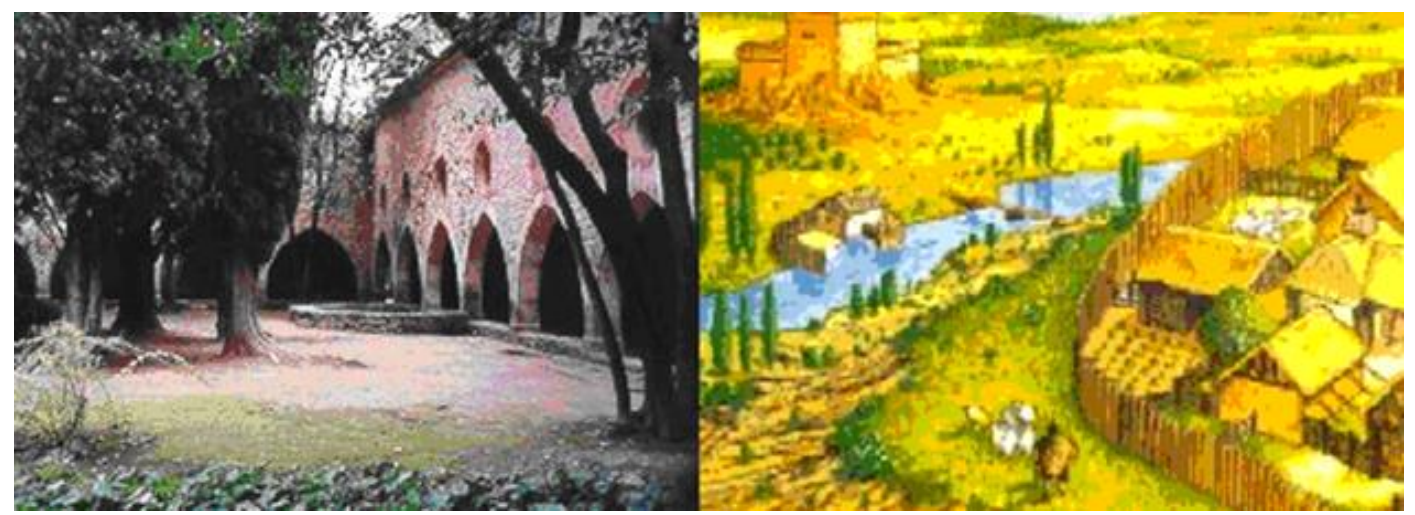

Figure 5. Medieval landscape: comparable and interpretive mosaic.

Source: Elaborated by the authors.

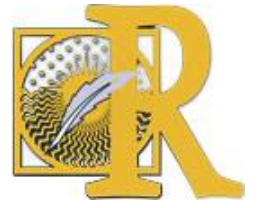




\section{Conclusions}

As we have presented throughout this work, Environmental Education must be integrated curricula in other areas and subjects. From an interdisciplinary approach, it is possible to achieve educational objectives more efficiently and productively. In such an important and necessary context for the awareness and sensitization of the new generations, the contrary would be inexcusable. The environment, and specifically the agricultural landscape, is fundamental to know the historical evolution of the human being. And in parallel, knowing history allows us to see how the landscape has evolved according to historical development. Through the landscape, we can establish a point of reference accessible to the learner for his or her understanding. As Novo (1985: 16) points out, "it is an open text that provides us with the keys for reading and understanding our history, for the understanding of the progress and appreciation of the inheritance that our predecessors have bequeathed to us and that we have to transmit to future generations with the positive contribution of our step". In very few instances like the current era, in the XXI century, in which the environment is so threatened that it is even difficult to venture optimism towards its survival, it becomes essential that the students can understand that its conservation is in our hands; through the modification of our behavior, it must assert itself as one of the primary objectives of any educational curriculum (Gómez Galán, 2018a).

In that sense, we would also be taking, in the holistic context of environmental education, a moral and ethical dimension. Of course, it is essential to address these contents in the educational process from this perspective, which some authors such as Sosa (1990), and many others (Riechmann, 2004; Minteer and Collins, 2005; Norton, 2008; Thompson, 2008; Di Norcia, 2017; Batavia, Bruskotter and Nelson, 2020; Washington and Maloney, 2020), call ecological ethics, and it would take us a long time to develop. In our case, we believe that it is essential, and as urgent as possible, to abandon our anthropocentric vision of the universe and embrace all sentient beings in our ethical sphere (Gómez Galán, 2005 and 2016b; Saari and Gómez Galán, 2018 and 2019). The agricultural landscape is presented as an essential curricular content in any process of Environmental Education, which transcends the specific field of an area, subject or content, and which can be analyzed, studied, and understood from other academic disciplines, from interdisciplinarity, to achieve the basic pursued objectives. In this way, the student will be able to understand that the environmental problem is part of his or her life, which is not isolated, alien to the self. Since to "unite education to life, invent or rediscover an education in close symbiosis with the environment; in this sense, it is undoubtedly the perspective in which remedies must be sought." Learn to live, learn throughout a lifetime" (Faure, 1976). We are too lightly playing too much in it. Education is, definitely, the best remedy for our problems.

\section{References.}

- Aarnio-Linnanvuori, E. (2019). How do teachers perceive environmental responsibility? Environmental Education Research, 25(1), 46-61.

- Aragunde-Kohl, U., Gómez Galán J., Lázaro Pérez, C., \& Martínez López, J. A. (2020). Interaction and emotional connection with pets: A descriptive analysis from Puerto Rico. Animals, 10(11), 2117.

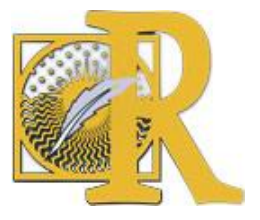

Fecha de recepción: 13-11-2020 Fecha de aceptación: 15-11-2020

Gómez-Galán, J., Figueroa-Miranda, O., Lázaro-Pérez, C., \& Martínez-López, J. A. (2021). Propuesta de diseño para un enfoque interdisciplinario de la educación ambiental: Análisis teórico de una práctica innovadora International Journal of Educational Research and Innovation (IJERI), 16, 142-161 ISSN: 2386-4303 DOI https://doi.org/10.46661/ijeri.5424 
- Ardoin, N. M., Bowers, A. W., \& Gaillard, E. (2020). Environmental education outcomes for conservation: A systematic review. Biological Conservation, 241, 108224.

- Batavia, C., Bruskotter, J. T., \& Nelson, M. P. (2020). Pathways from environmental ethics to pro-environmental behaviours? Insights from psychology. Environmental Values, 29(3), 317-337.

- Bianchi, R. M. (2007). El Paisaje y el aprendizaje significativo de la historia y las ciencias sociales. Espacio Regional, Revista de Estudios Sociales, 2(4), 21-26.

- Breiting, S., \& Mogensen, F. (1999). Action competence and environmental education. Cambridge Journal of Education, 29(3), 349-353.

- Busto, J. L., García García P., Fernández Cepedal, G., \& Vázquez, V. M. (1982). Aula abierta. Cuadernos de Pedagogía, 91, 70-73.

- Casas, M. \& Erneta, L. (2015). El paisaje en la educación secundaria obligatoria. una oportunidad educativa en el cambio curricular LOE-LOMCE. Didáctica Geográfica, 16, 4571.

- Casas, M. \& Puig, J. (2017). El impacto ambiental: una herramienta con un gran potencial para la formación ambiental. Publicaciones Didácticas, 84, 362-371.

- Chawla, L. (2015). Benefits of nature contact for children. Journal of Planning Literature, 30(4), 433-452.

- Chen, J. C., \& Martin, A. R. (2015). Role-play simulations as a transformative methodology in environmental education. Journal of Transformative Education, 13(1), 85-102.

- Christenson, M. A. (2004). Teaching multiple perspectives on environmental issues in elementary classrooms: A story of teacher inquiry. Journal of Environmental Education, 35(4), 3-17.

- Chrobak, R., Prieto R. M, Prieto, A. B., Gaido, A., \& Rotella, A. (2006). Una aproximación a las motivaciones y actitudes del profesorado de enseñanza media de la provincia de Neuquén sobre temas de educación ambiental. Revista Electrónica de Enseñanza de las Ciencias, 5(1), 31-50.

- Cid, O. (1992). Equipamientos escolares. Cuadernos de Pedagogía, 204, 18-22.

- Colin N. P. (1997). Editorial. A Happy Union: The INISTE Connection. Connect: UNESCO International Bulletin on Scientific and Technical Education and Environmental Education, 23(1), 2.

- Cotton, D. (2006). Teaching controversial environmental issues: neutrality and balance in the reality of the classroom. Educational Research, 48(2), 223-241.

- Dale, R. G., Powell, R. B., Stern, M. J., \& Garst, B. A. (2020). Influence of the natural setting on environmental education outcomes. Environmental Education Research, 26(5), 613631.

- Díez Hochleitner, R. (1993). Medio ambiente, desarrollo sostenible y educación, variables interdependientes. In R. Díez Hochleitner (ed.), Medio Ambiente y Educación (pp. 29-35). Barcelona, Spain: Fundación La Caixa.

- Di Norcia, V. (2017). Ecological ethics. Philosophy Now, 122, 48-49.

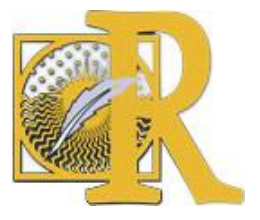


- Dionne, L. (1995). Globalisciences: Recueil d'activités en éducation dans une perspective mondiale. Montreal: Centre de Recherche pour le Développement International (CRDI) y Association des Professeurs de Sciences du Québec.

- Driver, R. (1986). Psicología cognoscitiva y esquemas conceptuales de los alumnos. Enseñanza de las Ciencias, 4, 49-53.

- Duby, G. (1987). Guerreros y Campesinos. Desarrollo Inicial de la Economía Europea (500-1200). Barcelona, Spain: Siglo XXI.

- Elías, M. L. (1987). Un acercamiento al pasado próximo. Cuadernos de Pedagogía, 151, 20-25.

- Elliot, J. (1990). La Investigación-Acción en Educación. Madrid, Spain: Morata.

- Elvira, P., \& Martí, A. (1995). Aula de naturaleza. Cuadernos de Pedagogía, 235, 52-57.

- Faure, E. (1976). Aprender a Ser. Madrid, Spain: Alianza Universidad.

- Fondation Charles Léopold Mayer pour le Progrès de l'Homme (FPH). (1997). Alliance pour un Monde Responsable et Solidaire. Paris, France: FPH.

- Frantz, C. M., \& Mayer, F. S. (2014). The importance of connection to nature in assessing environmental education programs. Studies in Educational Evaluation, 41, 85-89.

- García de la Vega, A. (2014). Didáctica del paisaje. realidad y reto educativo. Aula Verde, 42, 8-9.

- García Ruiz, M. \& López Pérez, I. (2005). Las actitudes relacionadas con la ciencia y el ambiente en profesores de Bachillerato de Oaxaca. VII Conference Enseñanza de las Ciencias, México.

- Gil, D. (1986). La metodología científica y la enseñanza de las ciencias: unas relaciones controvertidas. Enseñanza de las Ciencias, 4, 111-122.

- Glanz, J. (2014). Action Research: An Educational Leader's Guide to School Improvement. Lanham, Maryland, U.S.A.: Rowman \& Littlefield.

- Global Perspectives in Education (GPD). (1987). Report on the Study Commission on Global Education. New York, NY, U.S.A.: GPD.

- Gómez Galán, J. (1998). Educational System Evaluation and Quality. Minneapolis: College of Education and Human Development, University of Minnesota (Reprint, Cupey: UMET, 2015).

- Gómez Galán, J. (2001). La Monografía Histórica como Material Curricular en Bachillerato. Badajoz: Fondo de Educación y Promoción CREx.

- Gómez Galán, J. (2004). El Paisaje como Contenido Curricular de Educación Ambiental: Una Perspectiva Interdisciplinaria. Madrid: Facultad de Ciencias, Universidad Autónoma de Madrid.

- Gómez Galán, J. (2005). Animal rights education: An initiative at university. In N. Jukes, \& S. Martinsen (Eds.). Alternatives in the Mainstream: Innovations in Life Science Education and Training. Proceedings of the 2nd InterNICHE Conference, Oslo, Norway, 12-15 May 2005 (pp. 34-43); Leiscester: InterNICHE.

- Gómez Galán, J. (2008). Valores medioambientales en la educación. In Premios Nacionales de Investigación Educativa y Tesis Doctorales 2007 (pp. 55-108). Ministerio de Educación: Madrid.

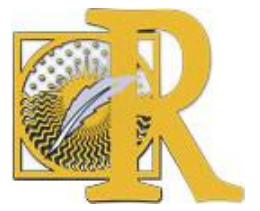

Fecha de recepción: 13-11-2020 Fecha de aceptación: 15-11-2020 
- Gómez Galán, J. (2010). Valores Medioambientales en la Educación: Situación del Futuro Profesorado de Extremadura ante la Ecología y el Cambio Climático. Madrid: Ministerio de Educación.

- Gómez Galán, J. (2014). La educación en valores medioambientales como base pedagógica de los procesos contemporáneos para el desarrollo sostenible. In J. C. Martínez Coll (ed.). Desarrollo Sostenible y Población. Málaga: Servicios Academicos Internacionales.

- Gómez Galán, J. (2015a). Media education as theoretical and practical paradigm for digital literacy: An Interdisciplinary Analysis. European Journal of Science and Theology, 11 (3), 31-44.

- Gómez Galán, J. (2015b). Historical and chronological time in education: A new theoretical framework. European Journal of Science and Theology, 11(5), 77-86.

- Gómez Galán, J. (2015c). Reestructuración metodológica y curricular de la educación ambiental: Principales líneas de actuación. In J. C. Martínez Coll (ed.). Desarrollo Local en un Mundo Global: Ecoespacios de Centros Urbanos. Málaga: Servicios Academicos Internacionales.

- Gómez Galán, J. (2016a). Education against global warming and climate change. En J. Gómez Galán, y A. Serrano (ed.) Climate Change: A Multidisciplinary View. Cupey: UMET Press.

- Gómez Galán, J. (2016b). Educación, Protección Animal y Bioética. Cupey: UMET.

- Gómez Galán, J. (2017). Nuevos estilos de enseñanza en la era de la convergencia tecnomediática: Hacia una educación holística e integral. International Journal of Educational Research and Innovation, 8, 60-78.

- Gómez Galán, J. (2018a). Enfoque holístico de la educación ambiental: El estudio del paisaje como modelo interdisciplinario. In J. C. Martínez Coll (ed.). Proceedings of I Congreso Online Internacional sobre Economía Social y Desarrollo Local Sostenible (pp. 283-292). Málaga: Universidad de Málaga.

- Gómez Galán, J. (2018b). Interdisciplinaridad en Educación Ambiental: Modelos y Desarrollo. Cupey: UMET.

- Gómez Galán, J. (2019). Perspectiva social y globalizadora de la educación ambiental: Transformación ética y nuevos retos. Andamios. Revista de Investigación Social, 16, 299 325.

- Gómez Galán, J. \& Mateos, S. (2002). Versatile spaces for the use of the information technology in education. In N. Mastorakis. Advances in Systems Engineering, Signal Processing and Communications (pp. 351-361). New York: WSEAS Press.

- Gómez Galán, J. \& Mateos, S. (2003). La enseñanza del tiempo histórico en la educación infantil. In Educación e Historia. Santa Cruz (Bolivia): ABNB.

- González Bernaldez, F. (1985). Invitación a la ecología humana. La adaptación efectiva al entorno. Madrid, Spain: Tecnos.

- Granit-Dgani, D., Kaplan, A., \& Flum, H. (2017). Theory-based assessment in environmental education: A tool for formative evaluation. Environmental Education Research, 23(2), 269-299.

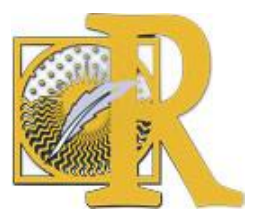

Fecha de recepción: 13-11-2020 Fecha de aceptación: 15-11-2020

Gómez-Galán, J., Figueroa-Miranda, O., Lázaro-Pérez, C., \& Martínez-López, J. A. (2021). Propuesta de diseño para un enfoque interdisciplinario de la educación ambiental: Análisis teórico de una práctica innovadora International Journal of Educational Research and Innovation (IJERI), 16, 142-161 ISSN: 2386-4303 DOI https://doi.org/10.46661/ijeri.5424 
- Halstead, J. M. (1996). Values and values education in schools. In J. M. Halstead, \& M. J. Taylor (Eds.), Values in Education and Education in Values (pp. 3-14). London, England: Falmer.

- Haydon, G. (2004). Values education: Sustaining the ethical environment. Journal of Moral Education, 33, 115-129.

- Henderson, J. A., \& Zarger, R. K. (2017). Toward political ecologies of environmental education. The Journal of Environmental Education, 48(4), 285-289.

- Herman, B. C., Sadler, T. D., Zeidler, D. L., \& Newton, M. H. (2018). A socioscientific issues approach to environmental education. In G. Reis \& J. Scott (Eds.), International Perspectives on the Theory and Practice of Environmental Education: A Reader (pp. 145161). Berlin, Germany: Springer.

- Higgins, P. (1996). Outdoor education for sustainability: making connections. Journal of Adventure Education and Outdoor Leadership, 13(4), 4-11.

- Hopkins, C., Damlamian, J., \& Ospina, G. L. (1996). Evolving towards education for sustainable development: an international perspective. Nature and Resources, 32, 2-11.

- Hopkinson, P., Hughes, P., \& Layer, G. (2008). Sustainable graduates: linking formal, informal and campus curricula to embed education for sustainable development in the student learning experience. Environmental Education Research, 14, 435-454.

- Ilesanmi, O. S. (2019). Opinion of environmental education students on teaching methods in higher education: A descriptive research. International Journal of Educational Excellence, 5(2), 65-74.

- Jickling, B., \& Sterling, S. (2017). Post-Sustainability and Environmental Education: Remaking Education for the Future. Berlin, Germany: Springer.

- Jorgenson, S. N., Stephens, J. C., \& White, B. (2019). Environmental education in transition: a critical review of recent research on climate change and energy education. The Journal of Environmental Education, 50(3), 160-171.

- Khalid, T. (2003). Pre-service high school teachers' perceptions of three environmental phenomena. Environmental Education Research, 9(1), 35-50.

- Knapp, C. E. (1983). A curriculum model for environmental values education. Journal of Environmental Education, 14, 22-26.

- Kopnina, H. (2012). Education for Sustainable Development (ESD): The turn away from "environment" in environmental education? Environmental Education Research, 18, 699717.

- Kopnina, H. (2015). Sustainability in Environmental Education: New Strategic Thinking. Environment, Development and Sustainability, 17(5), 987-1002.

- Legrand, L. (1982). Pour Collège Démocratique. París: La Documentation Francaise.

- Madeluero, J. (2005): El paisaje. Génesis de un concepto. Madrid, Spain: Adaba Editores.

- Malet, J. P. (2000). Teacher education for values education, guidance and materials. Journal of Moral Education, 29, 487-489.

- Martínez, R., \& Arrebola, J. C. (2016). La enseñanza del paisaje en España. Contexto \& Educação, 99, 9-33. 
- Matteson, J. (2013). The virtue of environmental creativity. Environmental Values, 22, 703723.

- Maxwell, B. (2006). Teaching right and wrong: a somewhat irritating expression. Journal of Philosophy of Education, 40, 405-412.

- McKenzie, M. (2005). The "post-post period" and environmental education research. Environmental Education Research, 11(4), 401-412.

- Mertler, C. A. (2016). Action Research: Improving Schools and Empowering Educators. London, England: Sage.

- Minteer, B. A., \& Collins, J. P. (2005). Why we need an ecological ethics. Frontiers in Ecology and the Environment, 3(6), 332-337.

- MOPTMA (1994). Construyendo el futuro. foro internacional de ong y movimientos sociales. Tratados Alternativos de Río'92. Madrid, Spain: MOPTMA.

- Nakagawa, Y., Verlie, B., \& Kim, M. (2020). Collectively engaging with theory in environmental education research. Australian Journal of Environmental Education, 36(1), 1-19.

- Nieda, J. (1993). El lugar de la educación ambiental. Cuadernos de Pedagogía, 34-39.

- Norton, B. G. (2008). Beyond positivist ecology: toward an integrated ecological ethics. Science and Engineering Ethics, 14(4), 581-592.

- Novo, M. (1985). Educación ambiental. Madrid: Anaya.

- Öhman, J. (2016). New Ethical Challenges within Environmental and Sustainability Education. Environmental Education Research, 22(6), 765-770.

- On, L. W. (2004). Values education for citizens in the New Century. Journal of Moral Education, 33, 616-618.

- Otto, S., \& Pensini, P. (2017). Nature- based environmental education of children: environmental knowledge and connectedness to nature, together, are related to ecological behaviour. Global Environmental Change, 47, 88-94.

- Palmer, J. A. (2002). Environmental Education in the 21st Century: Theory, Practice, Progress and Promise. London: Routledge.

- Pérez Torras, A. (1992). Currículum y coherencia ambiental. Cuadernos de Pedagogía, 204, 14-16.

- Pooley, J. A., \& O'Connor, M. (2000). Environmental education and attitudes. emotions and beliefs are what is needed. Environmental and Behavior, 32(5), 711-723.

- Porlán, R., \& Rivero, A. (1994). Investigación del medio y conocimiento escolar. Cuadernos de Pedagogía, 227, 28-31.

- Projet des Universités Francophones de l'Est du Canada (1995). L'Éducation dans une Perspective Planétaire: Une Passerelle vers l'Avenir. Montréal: Université de Montréal.

- Riechmann, J. (2004). Ética ecológica: propuestas para una reorientación. Barcelona, Spain: Icaria Editorial.

- Ross, N. (2020). Anthropocentric tendencies in environmental education: a critical discourse analysis of nature-based learning. Ethics and Education, 15(3), 355-370.

- Ruiz Sanz, J. P. (1989). Ecología y cultura en la ganadería de montaña. Madrid, Spain: Ministerio de Agricultura.

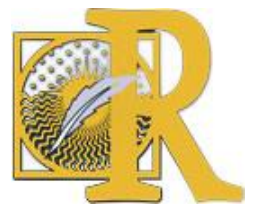

Fecha de recepción: 13-11-2020 Fecha de aceptación: 15-11-2020

Gómez-Galán, J., Figueroa-Miranda, O., Lázaro-Pérez, C., \& Martínez-López, J. A. (2021). Propuesta de diseño para un enfoque interdisciplinario de la educación ambiental: Análisis teórico de una práctica innovadora International Journal of Educational Research and Innovation (IJERI), 16, 142-161 ISSN: 2386-4303 DOI https://doi.org/10.46661/ijeri.5424 
- Saari, M. H., \& Gómez-Galán, J. (2018). Humane education as a new didactic for animal protection: Education as a driving force for social justice. In A. Linzey (Ed.). The Fifth Annual Oxford Animal Ethics Summer School Animal Ethics and Law: Creating Positive Change for Animals (pp. 1-9); Oxford: Centre for Animal Ethics, University of Oxford.

- Saari, M. H., \& Gómez-Galán, J. (2019). Innovative educational models for nonhuman animal protection: A case study on a European school scheme. International Journal of Educational Excellence, 5(1), 95-114.

- Sauvé, L. (1999). La Educación ambiental entre la modernidad y la posmodernidad: en busca de un marco de referencia educativo integrador. Tópicos en Educación Ambiental, 1(2), 7-25.

- Sauvé, L. (2005). Currents in environmental education: mapping a complex and evolving pedagogical field. Canadian Journal of Environmental Education, 10, 11-37.

- Scott, W., \& Oulton, C. (1998). Environmental values education: an exploration of its role in the school curriculum. Journal of Moral Education, 27, 209-224.

- Silcock, P., \& Duncan, D. (2001). Values acquisition and values education: Some proposals. British Journal of Educational Studies, 49, 242-259.

- Sireau, A. (1989). Educación y medio ambiente. Madrid: UNESCO y OEl/Popular.

- Sosa, N. M. (1990). Ética ecológica. Madrid: Ediciones Libertarias.

- Tillmanns, T. (2020). Learning sustainability as an effect of disruption. Environmental Education Research, 26(1), 14-26.

- Thompson, P. B. (2008). Agrarian philosophy and ecological ethics. Science and Engineering Ethics, 14(4), 527.

- UNESCO (1980). Environmental Education in the Light of the Tbilisi Conference. (Versión en español: La Educación Ambiental. Las Grandes Orientaciones de la Conferencia de Tbilisi. Paris, France: UNESCO.

- UNESCO (1997). Éduquer pour un avenir viable: Une vision transdisciplinaire pour l'action concertée. International Conference on Environment and Society. Thessaloniki: UNESCO.

- Van Poeck, K., \& Lysgaard, J. A. (2016). The roots and routes of environmental and sustainability education policy research. Environmental Education Research, 22(3), 305318.

- Wals, A. E., Brody, M., Dillon, J., \& Stevenson, R. B. (2014). Convergence between Science and Environmental Education. Science, 344(6184), 583-584.

- Wals, A., Weakland, J., \& Corcoran, P. B (2017). Preparing for the Ecocene: Envisioning futures for environmental and sustainability education. Japanese Journal of Environmental Education, 26(4), 71-76.

- Washington, H., \& Maloney, M. (2020). The need for ecological ethics in a new ecological economics. Ecological Economics, 169, 106478. 